\title{
FAKTOR YANG BERHUBUNGAN DENGAN KEJADIAN INFEKSI SALURAN PERNAPASAN AKUT (ISPA) PADA BALITA DI PUSKESMAS MABODO KABUPATEN MUNA TAHUN 2018
}

\author{
Fithria ${ }^{1}$ Junaid ${ }^{2}$ Harleli $^{3}$ Ramlah $^{4}$ \\ 1,2,3,4 Fakultas Kesehatan Masyarakat, Universitas Halu Oleo \\ 1fithria.ahmad@gmail.com2junaidjunaid1958@gmail.com3leli.har63@gmail.com4ramlahr06@gmail.com
}

\begin{abstract}
Infeksi Saluran Pernapasan Akut (ISPA) merupakan penyakit menular yang menjadi penyebab utama kematian pada anak usia $<5$ tahun di dunia. Hampir 7 juta anak meninggal akibat ISPA setiap tahun. Di Indonesia, ISPA masih menjadi masalah kesehatan utama dan merupakan penyebab utama kunjungan pasien di Puskesmas (40\%-60\%) dan rumah sakit (15\%-30\%). Penelitian ini bertujuan untuk mengetahui faktor yang berhubungan dengan kejadian infeksi saluran pernapasan akut (ISPA) pada balita di Puskesmas Mabodo Kabupaten Muna tahun 2018. Jenis penelitian ini adalah kuantitatif dengan menggunakan pendekatan cross sectional study. Populasi dalam penelitian ini adalah semua balita di Puskesmas Mabodo Kabupaten Muna yang terdaftar pada bulan oktober - bulan desember 2018 dan sampelnya diambil secara purposive sampling sebanyak 53 balita. Data dianalisis dengan Chi-square dengan 95\%. Hasil penelitian menunjukan tidak ada hubungan antara status gizi ( $p$ value $=0,418)$, status imunisasi $(p$ value $=0,391$ ) dan ada hubungan antara keberadaan anggota keluarga yang merokok ( $p$ value $=0,003$ ), penggunaan bahan bakar biomass ( $p$ value $=0,036$ ) dengan kejadian ISPA pada balita di Puskesmas Mabodo Kabupaten Muna Tahun 2018. Disarankan bagi tenaga kesehatan (Puskesmas) hendaknya memberikan konseling kepada Ibu yang memiliki balita di Puskesmas Mabodo yang mengalami penyakit ISPA untuk dapat mengurangi tingkat terjadinya penyakit ISPA tersebut.
\end{abstract}

Kata kunci: ISPA, Balita, Faktor kejadian ISPA

\begin{abstract}
Acute Respiratory Infection (ARI) is an infectious disease that is the leading cause of death in children aged $<5$ years in the world. Every year, almost 7 million children die because of ARI. In Indonesia, ARI was still a major health problem and was a major cause of patient visited in Puskesmas (40\% -60\%) and hospitals $(15 \%-30 \%)$. This study aimed to determine the factors associated with the incidence of acute respiratory infections (ARI) in chidren under five years in Mabodo Health Center, Muna Regency in 2018. The type of study was quantitative study with cross sectional study approach. The population in this study were all chidren under five years in Mabodo Health Center, Muna Regency, registered in October - December 2018 and the samples were taken by purposive sampling as many as 53 chidren under five years. Data were analyzed by Chi-square with $95 \%$. The results showed that there was no relationship between nutritional status ( $p$ value $=0.418$ ) or immunization status ( $p$ value $=0.391$ ) with the incidence of ARI in children under five years, but there was a relationship between the presence of smoking family members ( $p$ value $=0.003$ ), biomass fuel use ( $p$ value $=0.036$ ) with the incidence of ARI in children under five in Mabodo District Muna Health Center in 2018. It was recommended that health workers (Puskesmas) should provide counseling to mothers who have children under five years at the Mabodo Community Health Center who have ARI to reduce the rate of ARI disease.
\end{abstract}

Keywords: ARI, children under five years, ARI incidence factors 


\section{PENDAHULUAN}

Infeksi Saluran Pernapasan Akut (ISPA) adalah infeksi akut yang melibatkan organ saluran pernapasan bagian atas dan saluran pernapasan bagian bawah. Infeksi Saluran Pernapasan Akut (ISPA) merupakan penyakit menular yang menjadi penyebab utama kematian pada anak usia $<5$ tahun di dunia. Hampir 7 juta anak meninggal akibat ISPA setiap tahun. Kasus terbanyak terjadi di Bahamas (33\%), Romania (27\%), Timor Leste (21\%), Afganistan (20\%), Lao (19\%), Madagascar (18\%), Indonesia (16\%), dan India $(13 \%)^{1}$.

Di Indonesia, ISPA masih menjadi masalah kesehatan utama dan merupakan penyebab utama kunjungan pasien di Puskesmas (40\%-60\%) dan rumah sakit (15\%-30\%) ${ }^{2}$. Angka cakupan penemuan ISPA pada balita di Indonesia tahun 2014 tidak mengalami perkembangan berarti yaitu berkisar antara 20\%-30\%. Pada tahun 2015 terjadi peningkatan menjadi $63,45 \%$ dan menjadi $65,27 \%$ pada tahun 2016. Adanya peningkatan cakupan pada tahun 2015 karena perubahan angka perkiraan kasus dari $10 \%$ menjadi $3,55 \%$, selain itu ada peningkatan dalam kelengkapan pelaporan dari 83,08\% pada tahun 2014 menjadi 91,91\% pada tahun 2015 dan $94,12 \%$ pada tahun $2016^{3}$.

Menurut data profil kesehatan Provinsi Sulawesi Tenggara Infeksi Saluran Pernapasan Akut (ISPA) merupakan penyakit yang paling sering berada dalam daftar 10 (sepuluh) penyakit terbanyak di puskesmas maupun di rumah sakit. Tahun 2013 di Provinsi Sulawesi Tenggara, terdapat (6,67\%) penderita ISPA dan pada tahun 2014 di Provinsi Sulawesi Tenggara, terdapat (4,49\%) penderita ISPA dan pada tahun 2015 terdapat (2,22\%) penderita ISPA ${ }^{4}$.

Menurut data Dinas Kesehatan Kabupaten Muna pada tahun 2012 jumlah penderita ISPA pada balita sebanyak 2.525 orang, tahun 2013 sebanyak 1.912 orang, tahun 2014 sebanyak 1.805, dan pada tahun 2015 sebanyak 1.700 orang. Sedangkan pada tahun 2014 sebanyak 522 kasus dan tahun 2015 penderita ISPA Pneumonia pada balita tercatat sebanyak 328 kasus. Berdasarkan Profil salah satu Puskesmas yang ada di Kabupaten Muna yaitu Puskesmas Mabodo tahun 2017 angka kejadian ISPA di Puskesmas tersebut berada di urutan pertama pada sepuluh penyakit terbesar setiap tiga tahunnya yaitu tahun 2015 sebanyak 2902 kasus, tahun 2016 sebanyak 2488 kasus dan tahun 2017 sebanyak 2348 kasus ${ }^{5}$

Tingginya angka kejadian ISPA pada balita secara umum dipengaruhi oleh faktor individu (umur, status gizi, imunisasi yang tidak lengkap, ASI eksklusif) faktor perilaku (kebiasaan merokok, bahan bakar memasak, penggunaan obat nyamuk). Faktor terjadinya ISPA terkait lingkungan fisik rumah (kepadatan hunian, ventilasi, kelembaban, letak dapur, jenis lantai, jenis dinding) faktor sosial ekonomi (pendidikan orang tua, penghasilan orang tua) ${ }^{6}$.

Berdasarkan penelitian sebelumnya menunjukkan bahwa terdapat hubungan antara status gizi dan ISPA karena status gizi mempengaruhi daya tahan tubuh, dimana semakin rendah status gizi seorang balita maka semakin rendah pula daya tahan tubuh balita tersebut, maka balita semakin rentan untuk terinfeksi ${ }^{7}$. Hasil ini sejalan dengan teori yang mengatakan bahwa salah satu faktor risiko yang dapat mempengaruhi timbulnya penyakit ISPA pada anak adalah faktor status gizi. Anak usia di bawah lima tahun merupakan kelompok umur yang rawan dengan gangguan gizi dan rawan terhadap penyakit serta telah lama diketahui adanya interaksi senergis antara malnutrisi dan infeksi ${ }^{8}$.

Berdasarkan penelitian Putra, status imunisasi merupakan faktor yang meningkatkan mortalitas ISPA. Bayi dan balita yang mempunyai status imunisasi lengkap bila menderita ISPA perkembangan penyakitnya tidak akan menjadi lebih berat. Karena sebagian besar kematian ISPA berasal dari jenis ISPA yang berkembang dari penyakit yang dapat dicegah dengan imunisasi seperti difteri, pertusis, campak, maka peningkatan cakupan imunisasi akan berperan besar dalam upaya pemberantasan ISPA. Ketidaklengkapan imunisasi membuat antibody aktif anak tidak terbentuk dan akan mudah terserang penyakit ISPA ${ }^{9}$.

Faktor perilaku juga dapat memperbesar risiko terjadinya penyakit ISPA pada balita salah satunya terdapat anggota keluarga yang merokok di dalam rumah. Paparan Asap rokok bukan hanya menjadi penyebab langsung kejadian ISPA pada balita, tetapi menjadi faktor tidak langsung yang diantaranya dapat melemahhkan daya tahan tubuh balita. Asap rokok dapat menurunkan kemampuan makrofag membunuh bakteri. Asap rokok juga diketahui dapat merusak ketahanan lokal paru, seperti kemampuan pembersihan mukosiliaris, maka adanya anggota keluarga yang merokok terbukti merupakan faktor risiko yang dapat menimbulkan gejala gangguan pernafasan pada anak balita ${ }^{10}$.

Berdasarkan permasalahan tersebut, maka peneliti tertarik untuk melakukan penelitian mengenai faktor yang berhubungan dengan kejadian ISPA di Puskesmas Mabodo khususnya pada balita. 


\section{METODE}

Jenis penelitian ini adalah kuantitatif dengan menggunakan pendekatan cross sectional study. Populasi dalam penelitian ini adalah semua balita di Puskesmas Mabodo Kabupaten Muna yang terdaftar pada bulan oktober - bulan desember 2018 sebanyak 193 balita, tehnik pengambilan sampel yaitu dengan tehnik purposive sampling dengan jumlah sampel sebanyak 53 responden. Data dianalisis secara univariat dan bivariat dengan menggunakan uji Chisquare. Hasil penelitian pada tingkat kepercayaan 95\%. Uji Chi-square dilakukan untuk melihat besar faktor risiko variabel independen terhadap variabel dependen

\section{HASIL DAN DISKUSI}

Hubungan Status Gizi dengan kejadian ISPA pada balita di Puskesmas Mabodo Kabupaten Muna Tahun 2018

Gizi merupakan faktor yang dapat meningkatkan daya tahan tubuh dari serangan penyakit. Keadaan gizi merupakan refleksi persediaan gizi dalam tubuh. Tingkat pertumbuhan fisik dan imunologik seseorang dipengaruhi oleh adanya persediaan gizi dalam tubuh dan kekurangan zat gizi akan meningkatkan kerentanan dan beratnya infeksi suatu penyakit ${ }^{11}$.

\begin{tabular}{lccc}
\hline Tabel 1 & $\begin{array}{l}\text { Distribusi Responden Menurut Kejadian ISPA Pada Balita di Puskesmas Mabodo Kabupaten } \\
\text { Muna Tahun 2018 }\end{array}$ & & Persentase (\%) \\
\hline No. & Kejadian ISPA & Frekuensi (n) & 67.9 \\
\hline 1 & Menderita & 36 & 32.1 \\
\hline 2 & Tidak Menderita & 17 & $\mathbf{1 0 0}$ \\
\hline
\end{tabular}

Sumber : Data Sekunder, Februari 2019

Tabel 2. Hubungan status gizi dengan kejadian ISPA pada balita di Puskesmas Mabodo Kabupaten Muna Tahun 2018

\begin{tabular}{|c|c|c|c|c|c|c|c|}
\hline \multirow{3}{*}{ No. } & \multirow{3}{*}{ Status Gizi } & \multicolumn{4}{|c|}{ Kejadian ISPA } & \multirow[b]{2}{*}{ Jumlah } & \multirow{3}{*}{ pValue } \\
\hline & & \multicolumn{2}{|c|}{$\begin{array}{l}\text { Menderita } \\
\text { ISPA }\end{array}$} & \multicolumn{2}{|c|}{$\begin{array}{l}\text { Tidak Menderita } \\
\text { ISPA }\end{array}$} & & \\
\hline & & $\mathrm{n}$ & $\%$ & $\mathrm{n}$ & $\%$ & $\%$ & \\
\hline 1 & Gizi Baik & 29 & 54.7 & 12 & 22.6 & 4177.4 & \\
\hline \multirow[t]{2}{*}{2} & Gizi Kurang & 7 & 13.2 & 5 & 9.4 & 1222.6 & 0,418 \\
\hline & Total & 36 & 67.9 & 17 & 32.1 & 53100 & \\
\hline
\end{tabular}

Sumber : Data Primer, Februari 2019

Tabel 3. Hubungan status imunisasi dengan kejadian ISPA pada balita di Puskesmas Mabodo Kabupaten Muna Tahun 2018

\begin{tabular}{|c|c|c|c|c|c|c|c|c|}
\hline \multirow{3}{*}{ No. } & \multirow{3}{*}{ Status Imunisasi } & \multicolumn{4}{|c|}{ Kejadian ISPA } & \multirow{2}{*}{\multicolumn{2}{|c|}{ Jumlah }} & \multirow{3}{*}{ oValue } \\
\hline & & \multicolumn{2}{|c|}{$\begin{array}{l}\text { Menderita } \\
\text { ISPA }\end{array}$} & \multicolumn{2}{|c|}{$\begin{array}{l}\text { Tidak Menderita } \\
\text { ISPA }\end{array}$} & & & \\
\hline & & $\mathrm{n}$ & $\%$ & $\mathrm{n}$ & $\%$ & $\mathrm{n}$ & $\%$ & \\
\hline 1 & Lengkap & 31 & 58.5 & 16 & 30.2 & 38 & 88.7 & \\
\hline 2 & Tidak Lengkap & 5 & 9.4 & 1 & 1.9 & 32 & 11.3 & 0.005 \\
\hline & Total & 36 & 67,9 & 17 & 32,1 & 53 & 100 & \\
\hline
\end{tabular}

Sumber :Data Primer, Februari 2019 
Tabel 4. Hubungan keberadaan anggota keluarga yang merokok dengan kejadian ISPA pada balita di Puskesmas Mabodo Kabupaten Muna Tahun 2018

\begin{tabular}{|c|c|c|c|c|c|c|c|c|}
\hline \multirow{3}{*}{ No. } & \multirow{3}{*}{$\begin{array}{c}\text { Anggota Keluarga } \\
\text { Merokok }\end{array}$} & \multicolumn{4}{|c|}{ Kejadian ISPA } & \multirow{2}{*}{\multicolumn{2}{|c|}{ Jumlah }} & \multirow{3}{*}{ oValue } \\
\hline & & \multicolumn{2}{|c|}{$\begin{array}{l}\text { Menderita } \\
\text { ISPA }\end{array}$} & \multicolumn{2}{|c|}{$\begin{array}{c}\text { Tidak Menderita } \\
\text { ISPA }\end{array}$} & & & \\
\hline & & $\mathrm{n}$ & $\%$ & $\mathrm{n}$ & $\%$ & $\mathrm{n}$ & $\%$ & \\
\hline 1 & Ada & 31 & 58,5 & 8 & 15,1 & 39 & 73,6 & \multirow{3}{*}{0,003} \\
\hline 2 & Tidak Ada & 5 & 9,4 & 9 & 17 & 14 & 26,4 & \\
\hline 00 & Total & 36 & 67,9 & 17 & 32,1 & 53 & & \\
\hline
\end{tabular}

Sumber :Data Primer, Februari 2018

Tabel 5. Hubungan penggunaan bahan bakar biomass dengan kejadian ISPA pada balita di Puskesmas Mabodo Kabupaten Muna Tahun 2018

\begin{tabular}{|c|c|c|c|c|c|c|c|c|}
\hline \multirow{3}{*}{ No. } & \multirow{3}{*}{$\begin{array}{c}\text { Penggunaan Bahan } \\
\text { Bakar Biomass }\end{array}$} & \multicolumn{4}{|c|}{ Kejadian ISPA } & \multirow{2}{*}{\multicolumn{2}{|c|}{ Jumlah }} & \multirow{3}{*}{$\rho$ Value } \\
\hline & & \multicolumn{2}{|c|}{$\begin{array}{l}\text { Menderita } \\
\text { ISPA }\end{array}$} & \multicolumn{2}{|c|}{$\begin{array}{c}\text { Tidak Menderita } \\
\text { ISPA }\end{array}$} & & & \\
\hline & & $\mathrm{n}$ & $\%$ & $\mathrm{n}$ & $\%$ & \multicolumn{2}{|c|}{$\mathrm{n} \quad \%$} & \\
\hline 1 & Menggunakan & 32 & 60,4 & 11 & 20,8 & 43 & 81,1 & \multirow{3}{*}{0,036} \\
\hline 2 & Tidak Menggunakan & 4 & 7,5 & 6 & 11,3 & 10 & 18,9 & \\
\hline & Total & 36 & 67,9 & 17 & 32,1 & 53 & 100 & \\
\hline
\end{tabular}

Sumber :Data Primer, Februari 2019 
Dari hasil penelitian ini untuk melihat status gizi balita digunakan indeks antropometri berat badan menurut umur $(B B / U)$ sehingga diperoleh hasil yang menunjukkan bahwa balita yang status gizinya baik lebih banyak dibandingkan dengan balita yang status gizinya kurang. Berdasarkan kenyataan dilapangan hal ini disebabkan karena jumlah anggota keluarga responden kebanyakan hanya terdiri dari 3 anggota keluarga yaitu ayah, ibu, dan anak sehingga besar kemungkinan biaya yang diperlukan untuk memenuhi kebutuhan gizi anggota keluarga terutama untuk balita akan lebih sedikit dibandingkan dengan yang jumlah anggota keluarganya lebih banyak, sehingga pemenuhan kebutuhan gizinya akan lebih maksimal. Hal ini sesuai dengan teori yang dikemukakan oleh Setiasih, yaitu besarnya keluarga juga termasuk salah satu faktor yang dapat mempengaruhi status gizi balita, dimana jumlah pangan yang tersedia untuk suatu keluarga besar mungkin cukup untuk keluarga yang besarnya setengah dari keluarga tersebut, tetapi tidak cukup untuk mencegah gangguan gizi pada keluarga besar tersebut ${ }^{12}$. Selain itu, persediaan bahan-bahan pokok masyarakat disana mudah didapatkan dipasar tradisional yang lokasinya tidak terlalu jauh dari pemukiman warga dan kebanyakan dari mereka memanfaatkan pekarangan rumah sebagai tempat untuk berkebun seperti tempat menanam jagung, umbi-umbian, sayur-sayuran, dan sebagainya .

Dari hasil analisis bivariat menunjukkan bahwa tidak terdapat hubungan antara status gizi dengan kejadian ISPA pada balita di Puskesmas Mabodo Kabupaten Muna Tahun 2018. Hal ini disebabkan karena beberapa faktor lain yang dapat memperbesar resiko terjadinya ISPA yaitu balita sering terpapar asap dari hasil pembakaran pada saat memasak dan terpapar asap rokok, ada anggota keluarga yang lain mengalami ISPA, serta kondisi fisik rumah yang tidak memenuhi syarat kesehatan. Hal ini sesuai dengan pendapat Febrianto., et al yang mengatakan bahwa penyebab ISPA bukan hanya dari status gizi saja, tetapi juga dipengaruhi oleh faktor lain, seperti terpapar atau tidaknya dengan polusi. Balita dengan status gizi yang baik tetap bisa mengalami ISPA karena faktor lingkungan, misalnya anggota keluarga yang lain mengalami ISPA, sehingga tertular atau mungkin dipengaruhi faktor yang lain ${ }^{13}$.

Asap hasil pembakaran bahan bakar untuk memasak dengan konsentrasi tinggi dapat merusak mekanisme pertahanan paru sehingga akan memudahkan timbulnya ISPA. Asap pembakaran mengandung berbagai partikel, seperti Timbal $(\mathrm{Pb})$, Besi (Fe), Mangan (Mn), Arsen (Ar), Cadmium (Cd) yang dapat menyebabkan iritasi pada mukosa saluran napas sehingga saluran pernapasan mudah mengalami infeksi ${ }^{14}$. Partikel-partikel tersebut bila masuk ke dalam tubuh akan menyebabkan sel epitel dan silianya mudah rusak sehingga benda asing yang masuk ke dalam saluran pernapasan tidak dapat dikeluarkan. Dengan demikian, saluran pernapasan akan mengerut yang disebabkan oleh saraf- saraf yang terdapat di dalam saluran pernapasan terganggu. Respon yang diberikan tubuh bila mengalami keadaan tersebut adalah mengeluarkan sekret atau benda asing secara aktif melalui batuk ${ }^{15}$.

Selain itu juga keterpaparan asap rokok dapat merusak mekanisme pertahanan paru sehingga akan memudahkan timbulnya ISPA ${ }^{16}$. Menurut Wang., et al seorang yang bukan perokok tetapi menghisap asap rokok paling tidak 15 menit dalam satu hari selama satu minggu dikategorikan sebagai perokok pasif. Asap rokok lebih berbahaya bagi perokok pasif dari pada perokok aktif. Semakin lama balita terpapar asap rokok setiap hari maka semakin tinggi risiko balita terkena ISPA karena asap rokok mengganggu sistem pertahanan respirasi ${ }^{17}$. Hal ini didukung oleh Corwin yang mengatakan bahwa merokok mengganggu efektifitas sebagian mekanisme pertahanan respirasi. Produk-produk asap rokok merangsang pembentukan mukus dan menurunkan pergerakan silia. Dengan demikian terjadi penimbunan mukus dan peningkatan risiko pertumbuhan bakteri sehingga mempermudah timbulnya ISPA ${ }^{18}$. Depkes RI (2008) juga menambahkan akibat asap rokok seseorang bisa mengidap gangguan pernapasan bila secara terusmenerus terkontaminasi dengan asap rokok. Selain itu, bahaya asap rokok pada perokok pasif 3 kali lebih besar dari pada perokok aktif.

Selain itu sesuai pengamatan dilapangan, kondisi fisik rumah responden yang tidak memenuhi syarat kesehatan mengakibatkan suasana di dalam rumah tidak nyaman dan merugikan kesehatan khususnya saluran pernapasan, seperti kondisi rumah terlalu lembab, kondisi konstruksi dinding tidak kuat atau lapuk pencahayaan yang kurang, kurangnya ventilasi, dan pencemaran udara dalam rumah. Buruknya kondisi lingkungan pemukiman dapat memudahkan berkembangnya mikroorganisme dan virus. Hal ini sesuai dengan Keputusan Menteri Kesehatan Republik Indonesia Nomor 829/Menkes/SK/VII/1999 tentang persyaratan rumah tinggal menyebutkan bahwa jenis dinding tidak tembus pandang, terbuat dari bahan yang tahan terhadap cuaca, rata dan dilengkapi dengan ventilasi untuk sirkulasi udara. Dinding rumah yang baik menggunakan tembok, rumah yang berdinding tidak rapat seperti papan, kayu dan bambu dapat menyebabkan penyakit pernapasan yang berkelanjutan seperti ISPA, karena angin malam yang langsung masuk kedalam rumah.

Penelitian ini sejalan dengan penelitian yang dilakukan oleh Rahayu, et al (2015), dengan hasil uji Chi-Square diperoleh nilai $p=0,061$ yang berarti bahwa tidak ada hubungan antara status gizi dengan kejadian ISPA pada balita di Puskesmas Plered 
Kabupaten Purwakarta. Demikian pula sejalan dengan penelitian yang dilakukan oleh Kartiningrum (2016), dengan hasil uji Chi-Square diperoleh nilai $p=0.743$ yang berarti bahwa tidak ada hubungan antara status gizi dengan kejadian ISPA pada balita di Desa Kembang Sari Kecamatan Jatibanteng Kabupaten Situbondo Tahun 2016.

\section{Hubungan Status Imunisasi dengan kejadian ISPA pada balita di Puskesmas Mabodo Kabupaten Muna Tahun 2018}

Imunisasi merupakan upaya untuk meningkatkan atau menimbulkan kekebalan seseorang secara aktif terhadap penyakit, sehingga bila suatu saat terpajan dengan penyakit tersebut tidak akan sakit atau hanya mengalami sakit ringan ${ }^{19}$.

Dari hasil penelitian ini untuk melihat status imunisasi balita yaitu dengan melihat buku catatan KMS (kartu menuju sehat) balita yang masih disimpan oleh ibu balita dan juga melihat catatan imunisasi balita di puskesmas jika ibu balita lupa dimana mereka terakhir tempatkan KMS atau buku catatan tersebut telah rusak atau hilang. Dari hasil penelitian ini menunjukkan bahwa balita yang status imunisasinya lengkap lebih banyak dibandingkan dengan balita yang status imunisasinya tidak lengkap, hal ini disebabkan karena sebagian besar responden mengetahui bahwa imunisasi sangat penting bagi balita untuk mencegah terjadinya penyakit. Selain itu antusiasme warga untuk datang ke posyandu untuk mengimunisasi ataupun sekedar melihat perkembangan berat badan balitanya cukup tinggi dan juga karena dorongan keluarga dan tetangga atau masyarakat setempat.

Dari hasil analisis bivariat menunjukkan bahwa tidak terdapat hubungan antara status imunisasi dengan kejadian ISPA pada balita di Puskesmas Mabodo Kabupaten Muna Tahun 2018. Hal ini disebabkan karena masih tingginya penderita ISPA pada balita walaupun telah menerima imunisasi lengkap diakibatkan karena belum ada vaksin yang dapat mencegah ISPA secara langsung. Hal ini sejalan dengan teori Taisir yang mengatakan bahwa hubungan status imunisasi dengan kejadian ISPA pada balita tidak secara langsung. Kebanyakan kasus ISPA terjadi dengan disertai komplikasi campak yang merupakan faktor risiko ISPA yang dapat dicegah dengan imunisasi. Jadi imunisasi campak yang diberikan bukan untuk memberikan kekebalan tubuh terhadap ISPA secara langsung melainkan hanya untuk mencegah faktor yang dapat memacu terjadinya ISPA ${ }^{20}$.

Penyebab ISPA tidak dari faktor kekebalan tubuh atau imunitas saja, masih ada faktor-faktor lain yang menyebabkan terjadinya ISPA. Faktor yang dapat menyebabkan terjadinya ISPA antara lain usia, jenis kelamin, dan yang paling penting lingkungan ${ }^{21}$. Dari beberapa faktor ini akan saling berpengaruh satu sama lain, sehingga ISPA dapat terjadi terus menerus minimal 3 kali dalam 1 tahun. Selain itu, salah satu agen infeksius penyebab ISPA dalam hal ini virus, juga berperan dalam terjadinya ISPA yang tidak dapat dihindari dalam 1 tahun. Antigen virus yang merupakan sasaran dari antibodi berjumlah sangat besar yang terdiri atas galur yang berbeda genetiknya. Variasi antigen virus tersebut, menjadikan virus dapat resisten terhadap respon imun yang ditimbulkan oleh infeksi terdahulu, misal pandemi influenza. Juga ditemukan sejumlah besar epitop virus sehingga tidak memungkinkan untuk melakukan vaksinasi spesifik terhadap virus tersebut. Sehingga kita tidak dapat menghindari terjadinya ISPA dalam 1 tahun ${ }^{22}$.

Menurut Utami walaupun balita telah menerima imunisasi dasar lengkap balita masih beresiko mengalami ISPA karena terdapat juga beberapa faktor yang dapat mempengaruhi kejadian ISPA yaitu paparan dari virus, dan bakteri ${ }^{23}$. Menurut Hasan faktor lingkungan tempat tinggal anak dapat berpengaruh pada kejadian ISPA, dibutuhkan kualitas rumah tinggal yang baik serta memenuhi syarat kesehatan untuk menjaga lingkungan tetap sehat. Kualitas rumah tinggal yang baik ditentukan oleh jenis bahan bangunan yang digunakan, dan cukup luas untuk satu keluarga ${ }^{24}$.

Pada penelitian ini, ada satu balita yang status imunisasinya tidak lengkap tetapi tidak menderita ISPA. Hal ini disebabkan karena kondisi fisik rumah balita yang nyaman, tidak ada polusi asap didalam rumah karena dapur untuk memasak menggunakan kayu bakar ditempatkan berpisah dengan rumah dan juga tidak ada anggota keluarga yang merokok. Hal ini sesuai dengan teori Sumarmi yang mengatakan bahwa lingkungan rumah tepatnya kondisi fisik rumah merupakan salah satu faktor yang memberikan pengaruh besar terhadap status kesehatan penghuninya. Bila kondisi lingkungan buruk, derajat kesehatan akan rendah demikian sebaliknya. Oleh karena itu kondisi lingkungan pemukiman harus mampu mendukung tingkat kesehatan penghuninya 25 .

Penelitian ini sejalan dengan penelitian yang dilakukan oleh South (2016), dengan hasil uji Chi-Square diperoleh nilai $p=0,472$ yang berarti bahwa tidak ada hubungan antara status imunisasi dengan kejadian ISPA pada anak balita di Wilayah Kerja Puskesmas Ratatotok. Demikian pula sejalan dengan penelitian yang dilakukan oleh Tatawi (2013), dengan hasil uji Chi-Square diperoleh nilai $p=0,526$ yang berarti bahwa tidak ada hubungan yang bermakna antara status imunisasi dengan kejadian ISPA pada balita di Wilayah Kerja Puskesmas Tuminting Kota Manado.

Hubungan Keberadaan Anggota Keluarga Yang Merokok dengan kejadian ISPA pada balita di Puskesmas Mabodo Kabupaten Muna Tahun 2018 
Asap rokok dari orang tua atau penghuni rumah yang satu atap dengan balita merupakan bahan pencemaran dalam ruang tempat tinggal yang serius serta akan menambah resiko kesakitan dari bahan toksik pada anak-anak. Paparan yang terus menerus akan menimbulkan gangguan pernapasan terutama memperberat timbulnya infeksi saluran pernapasan akut dan gangguan paru-paru pada saat dewasa ${ }^{26}$.

Dari hasil penelitian ini, peneliti menggunakan kuesioner untuk mengetahui ada tidaknya anggota keluarga balita yang merokok, dan jika ada apakah anggota keluarga balita tersebut merokok disekitar balita atau tidak. Hasil penelitian ini menunjukkan bahwa balita yang ada anggota keluarganya yang merokok lebih banyak dibandingkan dengan balita yang tidak ada anggota keluarganya yang merokok. Berdasarkan pernyataaan ibu balita hal ini disebabkan karena anggota keluarga yang merokok tersebut yang hampir semua adalah ayah dari balita mengatakan bahwa dengan merokok dapat menghilangkan rasa lelah saat habis bekerja yang kebanyakan dari mereka bekerja diperkebunan dan juga sudah kebiasaan dari dulu yang susah untuk dihilangkan. Selain itu kurangnya kesadaran akan bahaya masalah kesehatan yang ditimbulkan dari kebiasaan merokok bagi dirinya maupun orang disekitarnya terutama bagi balitanya, hal ini dapat dilihat dari kebiasaan anggota keluarga yang merokok didalam rumah pada saat bersantai bersama, misalnya sambil nonton TV atau bercengkerama dengan anggota keluarga lainnya maupun dengan kerabat atau tetangga, tanpa memikirkan dampak yang ditimbulkan dari asap rokok tersebut.

Hasil analisis bivariat menunjukan bahwa ada hubungan antara keberadaan anggota keluarga yang merokok dengan kejadian ISPA pada balita di Puskesmas Mabodo Kabupaten Muna Tahun 2018. Hal ini disebabkan karena tingginya penderita ISPA pada balita yang ada anggota keluarganya yang merokok dibandingkan balita yang tidak ada anggota keluarganya yang merokok. Berdasarkan hasil wawancara dengan responden dan kenyataan dilapangan, hal ini disebabkan karena balita terpapar asap rokok dikarenakan anggota keluarga balita yang merokok tersebut merokok didalam rumah dan kondisi ventilasi dalam rumah balita tersebut tidak mendukung untuk masuk keluarnya udara di dalam ruangan sehingga memperbesar paparan asap rokok didalam rumah. Hal ini sesuai dengan teori yang dikemukakan oleh Rahmayatul yaitu kebiasaan merokok orang tua di dalam rumah menjadikan balita sebagai perokok pasif yang selalu terpapar asap rokok. Rumah yang orang tuanya mempunyai kebiasaan merokok berpeluang meningkatkan kejadian ISPA sebesar 7,83 kali dibandingkan dengan rumah balita yang orang tuanya tidak merokok di dalam rumah ${ }^{27}$.
Kebiasaan merokok di rumah akan merugikan anak-anak dan istri karena menjadi perokok pasif ${ }^{28}$. Udara yang tercemar oleh perokok akan mencemari orang yang tidak merokok disekitarnya. Beberapa penyelidikan menunjukkan bahwa anak-anak yang orang tuanya merokok akan mudah menderita penyakit gangguan pernapasan ${ }^{29}$. Terdapat seorang perokok atau lebih yang merokok di dalam rumah akan memperbesar resiko anggota keluarga menderita gangguan pernapasan serta dapat meningkatkan resiko untuk mendapat serangan ISPA khususnya pada balita ${ }^{30}$.

Bahan kimia yang berasal dari asap rokok merangsang permukaan sel saluran pernapasan sehingga mengakibatkan keluarnya lendir atau dahak. Mirip dengan rangsangan debu, virus atau bakteri pada saat flu. Bedanya adalah bahwa dahak yang ditimbulkan karena virus flu akan di dorong keluar oleh debu getar sepanjang saluran napas dengan menstimulasi reflek batuk. Sedangkan lendir yang disebabkan oleh pengaruh asap rokok yang lama tertahan di saluran pernapasan karena tidak dapat menstimulasi reflek batuk dapat menjadi tempat berkembangnya bakteri yang akan meningkatkan penyakit infeksi pernapasan termasuk ISPA, terutama pada kelompok umur balita yang memiliki daya tahan tubuh lemah, sehingga bila ada paparan asap, maka balita lebih cepat terganggu sistem pernapasannya seperti ISPA ${ }^{31}$.

Penelitian ini sejalan dengan penelitian yang dilakukan oleh Milo, et al (2015), dengan hasil uji ChiSquare diperoleh nilai $p=0,002$ yang berarti bahwa ada hubungan antara kebiasaan merokok dengan kejadian ISPA pada balita di Puskesmas Sario Kota Manado. Demikian pula sejalan dengan penelitian yang dilakukan Putri dan Irdawati (2017), dengan hasil uji Chi-Square diperoleh nilai $p=0,018$ yang berarti terdapat hubungan antara keberadaan anggota keluarga yang merokok denngan kejadian pneumonia pada anak usia 1-4 tahun di Wilayah Kerja Puskesmas Tawangsari Sukoharjo.

\section{Hubungan Penggunaan Bahan Bakar Biomass dengan kejadian ISPA pada balita di Puskesmas Mabodo Kabupaten Muna Tahun 2018}

Penggunaan bahan bakar untuk memasak di rumah tangga sangat berpengaruh terhadap faktor risiko kejadian ISPA yang dimana bahan bakarnya banyak mengeluarkan asap dan konstruksi rumah yang tidak memiliki ventilasi di dapur yang menyebabkan asap lama tinggal di dapur maupun perilaku ibu membawa anak ke dapur sehingga anak yang berada bersama ibu di dapur, anak tersebut sering terpapar asap yang juga mengakibatkan gangguan pernapasan pada balita ${ }^{32}$.

Dari hasil penelitian ini, peneliti menggunakan kuesioner untuk mengetahui bahan bakar apa yang 
digunakan untuk memasak, letak dapur, ada tidaknya ventilasi didapur, dan apakah pada saat memasak ibu balita membawa balitanya kedapur atau tidak. Hasil penelitian ini menunjukkan bahwa jumlah responden yang masih menggunakan bahan bakar biomass untuk memasak lebih banyak dibandingkan dengan responden yang tidak menggunakan bahan bakar biomass untuk memasak, hal ini disebabkan karena banyak dari warga disana yang lebih memilih kayu sebagai bakar untuk memasak, karena bahan bakar kayu mudah didapat, lebih ekonomis, masakan yang dimasak menggunakan bahan bakar kayu rasanya lebih nikmat dibandingkan dengan masakan yang menggunakan kompor gas atau kompor minyak tanah. Bahan bakar kayu dilokasi penelitian ini mudah didapat karena kawasannya masih banyak terdapat hutan sehingga mempermudah warga mengumpulkan ranting-ranting pohon yang sudah mengering untuk dijadikan bahan bakar memasak yang lokasi untuk mengambil ranting pohon tersebut tidak terlalu jauh dari rumah warga. Selain itu warga juga memperoleh bahan bakar kayu dengan membeli dan memesannya secara langsung pada penjual kayu bakar yang harganya tidak terlalu mahal dibandingkan dengan membeli minyak tanah atau gas. Biasanya hal ini terjadi pada saat musim penghujan yang pada saat musim ini kayu bakar yang kering susah didapat.

Hasil analisis bivariat menunjukan bahwa terdapat hubungan antara penggunaan bahan bakar biomass dengan kejadian ISPA pada balita di Puskesmas Mabodo Kabupaten Muna Tahun 2018. Hal ini disebabkan karena tingginya penderita ISPA pada balita yang masih menggunakan bahan bakar biomass dibandingkan dengan yang tidak menggunakan bahan bakar biomass. Hal ini sesuai dengan teori Sukar yaitu kejadian ISPA lebih banyak diderita oleh balita pada rumah tangga yang menggunakan bahan bakar dengan emisi asap yang banyak (kayu api dan minyak tanah) dibandingkan rumah yang menggunakan bahan bakar yang sedikit asapnya (LPG). Hal ini dikarenakan asap merupakan salah satu agen atau penyebab terjadinya ISPA pada balita. Asap dari penggunaan bahan bakar di rumah merupakan sumber utama polusi di udara. Sumber polusi ini bisa dihasilkan dari kegiatan-kegiatan dalam ruangan seperti memasak ${ }^{33}$.

Semakin banyak jumlah polutan dalam rumah tangga akan meningkatkan risiko kejadian ISPA pada balita dalam rumah tersebut. hal ini terlihat dari jumlah penderita ISPA yang lebih banyak diderita oleh balita pada rumah tangga yang lebih banyak penggunaan bahan bakarnya. Semakin banyak bahan bakar yang digunakan, maka semakin tinggi pula jumlah polutan dalam rumah yang akan mengganggu sistem pernapasan balita. Asap hasil pembakaran bahan bakar untuk memasak dengan konsentrasi tinggi dapat merusak mekanisme pertahan parusehingga akan memudahkan timbulnya ISPA ${ }^{34}$.

Berdasarkan hasil wawancara dengan responden dan kenyataan dilapangan, kebanyakan dari responden yang masih menggunakan bahan bakar biomass untuk memasak letak dapur berada didalam rumah dan ibu balita sering membawa balita didapur pada saat memasak sehingga menyebabkan balita tersebut terkena penyakit ISPA karena sering terpapar asap dari hasil pembakaran bahan bakar biomass. Hal ini sesuai dengan teori Singga dan Maran yaitu kejadian ISPA erat kaitanya dengan faktor resiko yaitu kondisi lingkungan rumah dan perilaku. Yang dimaksud dengan kondisi rumah adalah letak dapur dengan ruang keluarga dekat, terdapat asap di dalam rumah saat memasak, ruang dapur dengan ruang makan di gabung dan tidak ada lubang ventilasi di dapur. Sedangkan faktor perilaku adalah kebiasaan ibu membawa anak ke dapur saat memasak. Faktorfaktor risiko tersebut erat kaitannya dengan penggunaan bahan bakar dalam rumah tangga penderita ISPA. Contohnya kebiasaan ibu membawa anak ke dapur, akan meningkatkan risiko kejadian ISPA pada balita tersebut sebagai akibat dari seringnya balita terpapar polutan dari hasil pembakaran didapur. Demikian juga dengan kondisi rumah yang dapurnya dekat dengan ruang keluarga, ruang makan dan dapur digabung serta tidak adanya ventilasi akan meningkatkan risiko kejadian ISPA pada balita dirumah tangga tersebut. Pada rumah-rumah dengan kodisi tersebut, tingkat polusi akibat penggunaan bahan bakar dalam rumah akan lebih tinggi. Tingginya polusi dalam rumah dengan sendirinya menyebabkan balita dalam rumah tersebut rentan terhadap kejadian ISPA ${ }^{32}$. Teori yang dikemukakan oleh Hugo menambahkan bahwa balita yang terpajan oleh pencemaran dari hasil pemakaian kayu bakar untuk memasak dan kebiasaan membawa balita kedapur dapat menyebabkan balita terkena resiko 2,3 kali lebih besar mengalami penyakit ISPA dibandingkan balita yang tidak selalu dibawa kedapur menerima resiko 1,5 kali dibandingkan dengan yang tidak terkena pajanan asap dari kegiatan memasak didapur. Polusi udara dalam ruangan yang disebabkan paparan asap dari kegiatan memasak dengan pemakaian bahan bakar biomass (kayu, kotoran hewan, jerami) mempunyai hubungan yang signifikan dengan prevalensi ISPA pada balita ${ }^{11}$.

Penelitian ini sejalan dengan penelitian yang dilakukan oleh Wahyuningsih, et al (2017), dengan hasil uji Chi-Square diperoleh nilai $p=0,001$ yang berarti terdapat hubungan antara penggunakan jenis bahan bakar biomass denngan kejadian ISPA pada balita di wilayah pesisir Desa Kore Kecamatan Sanggar Kabupaten Bima Tahun 2014. Demikian pula sejalan dengan penelitian yang dilakukan oleh Rosana (2016), dengan hasil uji Chi-Square diperoleh nilai $p=0,003$ 
yang berarti terdapat hubungan antara penggunakan jenis bahan bakar biomass denngan kejadian ISPA pada balita di wilayah kerja Puskesmas Blado ${ }^{1}$.

\section{SIMPULAN DAN SARAN}

Berdasarkan hasil penelitian dan pembahasan tentang faktor yang berhubungan dengan kejadian ISPA pada balita di Puskesmas Mabodo Kabupaten Muna Tahun 2018. Maka dapat disimpulkan bahwa tidak ada hubungan status gizi dengan kejadian ISPA pada balita di Puskesmas Mabodo Kabupaten Muna Tahun 2018. Tidak ada hubungan status imunisasi dengan kejadian ISPA pada balita di Puskesmas Mabodo Kabupaten Muna Tahun 2018. Ada hubungan keberadaan anggota keluarga yang merokok dengan kejadian ISPA pada balita di Puskesmas Mabodo Kabupaten Muna Tahun 2018. Ada hubungan penggunaan bahan bakar biomass dengan kejadian ISPA pada balita di Puskesmas Mabodo Kabupaten Muna Tahun 2018.

Berdasarkan hasil penelitian dan pembahasan tentang faktor yang berhubungan dengan kejadian ISPA pada balita di Puskesmas Mabodo diharapkan kepada ibu balita hendaknya lebih memberikan makanan yang bergizi dan cukup energi untuk anaknya, aktif dalam mengikuti kegiatan posyandu setiap bulannya untuk memantau pertumbuhan dan perkembangan anak balita dan lebih aktif dalam mencari informasi tentang gizi balita melalui penyuluhan oleh tenaga kesehatan, konseling gizi dan melalui sumber informasi lainnya.Diharapkan kader bisa me nghimbau ibu-ibu baduta untuk selalu membawa anak untuk mendapatkan imunisasi dasar, dan keluarga khususnya suami ikut mengingatkan dan jika perlu menemani ibunya untuk membawa anaknya mendapatkan imunisasi dasar. Diharapkan anggota keluarga yang merokok tidak berada di dekat balita dan bagi yang menggunakan kayu bakar, gunakanlah kayu bakar yang benar-benar kering dan pastikan kayu tersebut terbakar secara sempurna, agar tidak banyak mengeluarkan asap, serta diusahakan tidak membawa balita ke dapur ketika memasak, sehingga memperkecil resiko balita terkena penyakit ISPA. Diharapkan bagi tenaga kesehatan (Puskesmas) hendaknya memberikan konseling kepada Ibu yang memiliki balita di Puskesmas Mabodo yang mengalami penyakit ISPA untuk dapat mengurangi tingkat terjadinya penyakit ISPA tersebut.

\section{DAFTAR PUSTAKA}

1. WHO. 2015. Acute Respiratory Infection. www.who.int. Diakses tanggal 15 Desember 2018.

2. Kemenkes RI. 2012. Pedoman Pengendalian Infeksi Saluran Pernapasan Akut. Jakarta: Kementrian Kesehatan RI 2012.
3. Kemenkes RI. 2016. Pedoman Pengendalian Infeksi Saluran Pernapasan Akut. Jakarta: Kementrian Kesehatan RI 2016.

4. Profil Kesehatan Sulawesi Tenggara Provinsi Sulawesi Tenggara Tahun 2015.

5. Profil Kesehatan Kabupaten Muna Tahun 2017.

6. Kartiningrum, E. D. 2016. Faktor Yang Mempengaruhi Kejadian Ispa Pada Balita Di Desa Kembang Sari Kec. Jatibanteng Kab.Situbondo. Hospital Majapahit. Vol. 8, No. 2, Hal. 29-41.

7. Almira. 2017. Hubungan Status Gizi Dengan Kejadian Infeksi Saluran Pernafasan Akut (ISPA) Pada Balita Di Wilayah Kerja Puskesmas Siantan Hilir. Jurnal ProNers. Vol. 2. No. 2. Hal. 1-10.

8. Hadiana, S.Y.M. 2013. Hubungan Status Gizi Terhadap Terjadinya Infeksi Saluran Pernapasan Akut (Ispa) pada Balita di Puskesmas Pajang Surakarta. Surakarta: Fakultas IImu Kesehatan UMS.57

9. Putra, A.S. 2014. Hubungan Faktor Lingkungan Rumah Dan Status Imunisasi Dengan Kejadian Ispa Pada Balita Di Puskesmas Pariaman Kelurahan Pauh Barat Di Kota Pariaman Tahun 2014. LPPM Stikes Yarsi. Vol. 3. No. 2. Hal. 1-9.

10. Wahyuningsih, S. 2017. Infeksi Saluran Pernafasan Akut (ISPA) pada Balita di Wilayah Pesisir Desa Kore Kecamatan Sanggar Kabupaten Bima. Higiene. Vol. 3. No. 2. Hal. 97-105.

11. Hugo, M. 2014. Pajanan Asap Dalam Rumah Terhadap Kejadian Ispa Nonpneumonia Pada Anak Balita Di Kabupaten Kapuas. Jurnal Kesehatan Reproduksi. Vol. 1. No. 1. Hal. 80-89.

12. Setiasih, E. 2011. Analisis Faktor - Faktor Yang Berhubungan Dengan Status Gizi Anak Usia (1 5 Tahun) Di Posyandu Cempaka Desa Ngrembel Kelurahan Gunungpati Kota Semarang. Jurnal Keperawatan. Vol. 4. No. 2. Hal. 147-170.

13. Febrianto W., Mahfoedz I. dan Mulyanti. 2015. Status Gizi Berhubungan Dengan Kejadian ISPA Pada Balita di Wilayah Kerja Puskemas Wonosari I Kabupaten Gunungkidul 2014. Jurnal Gizi dan Dietetik Indonesia, Vol. 3. No. 2. Hal. 113-118.

14. Syarif, S.W. 2009. Faktor-faktor yang Berhubungan dengan Kejadian Infeksi Saluran

Pernapasan Akut Pada balita di Wilayah Kerja Puskesmas Tarakan Kota Makassar Tahun 2009. FKM Unhas.

15. Kassamsi. 2008. Faktor yang Berhubungan dengan Kejadian Infeksi Saluran Pernapasan Akut (ISPA) pada Balita di Kelurahan Rembon Tahun 2008. FKM Unhas.

16. Rahajoe, N. 2008. Buku Ajar Respirologi Anak. Edisi Pertama. Badan Penerbit IDAl. Jakarta.

17. Wang C. P., Ma S. J., Xu X. F., et al., 2009. The prevalence of household second-hand smoke exposure and its correlated factors in six 
countriesofChina.http://www.pubmedcentral.nih. gov.

18. Corwin, E.J. 2009. Buku Saku Patofisiologi. Jakarta: ECG.

19. Hidayatullah, L.M., Y. Helmi, dan H. Aulia. 2016. Hubungan Antara Kelengkapan Imunisasi Dasar dan Frekuensi Infeksi Saluran Pernapasan Akut (ISPA) pada Balita yang Datang Berkunjung ke Puskesmas Sekip Palembang 2014. Jurnal Kedokteran Dan Kesehatan. Vol. 3. No. 3. Hal. 182193.

20. Taisir. 2005. Faktor-Faktor Yang Berhubungan Dengan Kejadian ISPA Pada Balita Di Kelurahan Lhok Bengkuang Kecamatan Tapaktuan Aceh Selatan Tahun 2005. Medan : FKM USU.

21. Wantania JM, Naning R, Wahani A. 2012. Infeksi respiratori akut. Dalam: Buku ajar respirologi anak IDAI. Jakarta: EGC.

22. Baratawidjaja, K.G. 2014 Imunologi dasar. Jakarta: Fakultas Kedokteran Universitas Indonesia.

23. Utami, S. 2013. Studi Deskriptif Pemetaan Faktor Resiko ISPA Pada Balita Usia 0-5 Tahun Yang Tinggal Di Rumah Hunian Akibat Bencana Lahar Dingin Merapi Di Kecamatan Salam Kabupaten Magelang. Fakultas IImu Keolahragaan Universitas Negeri Semarang. Semarang.

24. Hasan, N.R. 2012. Faktor-Faktor yang Berhubungan Dengan Kejadian ISPA Pada Balita Di Wilayah Kerja UPTD Kesehatan Luwuk Timur, Kabupaten Banggai Provinsi Sulawesi Tengah.

25. Sumarmi. 2014. Analisis Hubungan Kondisi Fisik Rumah Dengan Kejadian TB Paru BTA Positif Di Puskesmas Kotabumi II, Bukit Kemuning dan Ulak
Rengas Kab. Lampung Utara Tahun 2012. Jurnal Kedokteran Yarsi. Vol. 2. No. 22. Hal. 082-101.

26. Milo, S., A.Y. Ismanto, dan V.D. Kallo. 2015. Hubungan Kebiasaan Merokok Di Dalam Rumah Dengan Kejadian Ispa Pada Anak Umur 1-5 Tahun Di Puskesmas Sario Kota Manado. ejournal Keperawatan. Vol. 3. No. 2. Hal. 1-7.

27. Rahmayatul, F. 2013. Hubungan Lingkungan Dalam Rumah Terhadap ISPA Pada Balita. Jakarta.

28. Wahyu. 2008. Stroke Hanya Menyerang Orang Tua. Jakarta: Seri Kesehatan Populer.

29. Bustan, M.N. 2007. Epidemiologi Penyakit Tidak Menular. Jakarta: Rineka Cipta.

30. Epa Development. 2009. Fact Sheet: Respiratory Health Effect Passive Smoking. (Diakses tanggal 24 Maret 2019. Didapat dari: http://www.epa.gov/smokefree/pubs.

31. Trisnawati, Y, dan Juwarni. 2012. Hubungan Perilaku Merokok Orang Tua dengan Kejadian ISPA pada Balita di Wilayah Kerja Puskesmas Rembang Kabupaten Purbalingga. Purwokerto: Akademi Kebidanan YLPP.

32. Singga, S. dan A.A. Maran. 2013. Penggunaan Bahan Bakar Dan Faktor Risiko Kejadian Ispa Pada Balita Di Kelurahan Sikumana. Jurnal Info Kesehatan. Vol. 11. No. 1. Hal. 348-355.

33. Sukar. 1996. Pengaruh Kualitas Lingkungan dalam Ruang Terhadap ISPA Pnemonia. Bandung: Buletin Penelitian Kesehatan.

34. Depkes RI. 2002. Pedoman Pemberantasan Penyakit Saluran Pernapasan Akut. Jakarta: Departemen Kesehatan RI. 